\title{
Prospects of freight traffic redirection from rail to water transport through the example of the Amur Basin and coal export transportation
}

\author{
Grigoriy Deruzhinskiy ${ }^{1}$, Petr Kurenkov ${ }^{2}$, Sergey Vakulenko ${ }^{2}$, Kirill Kalinin² , Maria Romenskaya $^{2}$ \\ ${ }^{1}$ Admiral Ushakov Maritime State University, 93, Lenin's avenue, Novorossiysk, 353924, Russia \\ ${ }^{2}$ Russian University of Transport RUT - MIIT, 9, building 9, Obraztsova street, Moscow, 127994, \\ Russia
}

\begin{abstract}
The authors consider the prospects for the development of coal industry and its export potential. The facts of the development of mass transportation of coal by rail in the direction of port transport hubs are given. There is an acute problem of finding new supply channels. In these conditions, it is proposed to start the implementation of a largescale project for the development of a multimodal transport scheme for the export of coal using river transport. During the 140-day navigation period along the rivers of the Amur Basin in the summer months, a large volume of export coal can be transported to the Far Eastern seaports. Three logistic schemes are proposed and a list of individual subprojects for the development of transport infrastructure for the needs of this project for the transportation of coal from Kuzbass, Krasnoyarsk Territory, Buryatia and Yakutia is given. It is proposed to organize transshipment from railway to river transport in three hubs: Sretensk, Dzhalinda and Verkhnezeisk. Each logistic scheme will be focused on a certain volume of transportation and has its own advantages and disadvantages. The authors invite the transport community to actively discuss this format of transportation due to the urgent need to find ways to develop cargo flows. Each of the three logistic schemes can be considered separately or in combination with others.
\end{abstract}

\section{Introduction}

According to analytical data [1], the world coal market is divided into three unequal parts. The European and North American markets in 2019 reduced the consumption of energy coal due to lower prices for natural gas and the increase in the share of renewable energy sources. In East and South Asia, steam coal consumption also declined due to the changes in demand in energy systems of countries. At the same time, in Southeast Asia coal kept its leading position in energy sector, but the growth in consumption in this market could not compensate the overall decline in demand in global market. In the markets of countries with developed economies, the important processes of changes in the market condition and the abandonment of coal are taking place. In developing countries, including the African continent, the importance of coal is not diminishing. The markets of Europe and the Mediterranean region geographically close to Kuzbass became unstable $[2,3]$ and coal miners turned to the east.

If we evaluate the plans of the domestic coal industry in general, then they can be characterized as positive. The strategy for the development of the Russian coal industry adopted in 2020 [4] provides the increase in coal production by 2035 to 485 million tons from 439.3 million tons in 2018. The strategy provides the export of coal according to a conservative logistics scheme through the existing sea basins with the development of the carrying and processing capacities of the railway and port infrastructure.

With the relative stability of coal consumption within Russia over time, export shipments continue

\footnotetext{
*Corresponding author: evropa@bk.ru
} 
to grow. The mined coal is delivered to international markets mainly by rail and sea traffic. Due to the geography of the location of the largest coal basins (Kuznetsk, Kansk-Achinsk, Yuzhno-Yakutsk, etc.), Russian coal overcomes an unprecedented distance by rail.

The estimated reserves of coal on our planet are several times larger than the reserves of oil, the production peak of which, according to some estimates, has already passed. In these conditions, due attention is being paid to dry cargo and the development of interaction between water (sea and river) and railway transport.

\section{Problem statement}

The current situation on the railways requires radical changes in the service of export bulk of cargo flows. The high priority of the transportation of coal, which has a controversial economic efficiency for Russian Railways, leads to the decrease in the attractiveness of railway transportation both for passenger transportation and for other categories of cargo tending towards the Trans-Siberian railway: timber cargo, oil products and agricultural cargo. Container traffic will not develop properly without the improvement of the conditions for cargo flows at the Eastern landfill. In these conditions, it is necessary to pay attention to the possibility of the use of river transport potential, namely the Amur River basin. The geography of export routes through the example of Kuzbass coals is shown in Figure 1. As we can see, the three most important export routes are in the direction of three port basins: Baltic, Black Sea and Far Eastern. Before boarding an ocean bulk carrier, coal from Kuzbass must travel $4000 \mathrm{~km}$ by rail when heading to Baltic ports, $4500 \mathrm{~km}$ when heading to ports of the Black Sea or $5500 \mathrm{~km}$ when heading to ports in the Far East. The need to transport large volumes of coal over long distances leads to the fact that in the ton-kilometer operation of Russian railways, coal comprises $44 \%$ and its share will continue to increase.

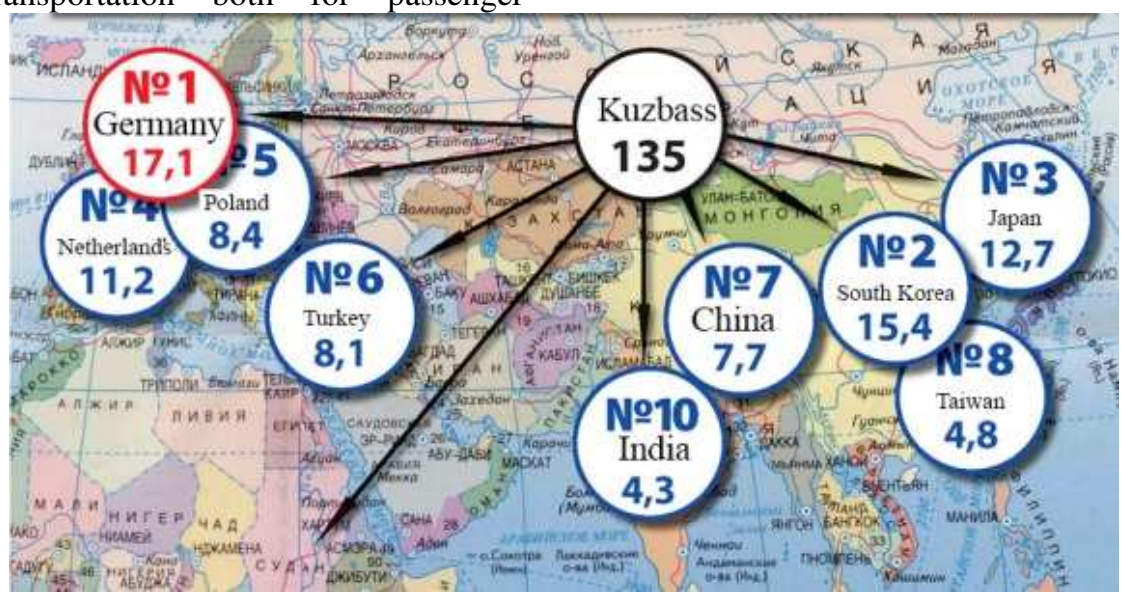

Figure1. Geography of export of the largest lots of coal from Kuzbass in 2019 (source Business portal of Kuzbass)

Coal mining in the Kuznetsk and Kansk-Achinsk coal basins is carried out by dozens of enterprises of various owners and production volumes. Shipment to railway transport takes place from about 120 enterprises of the Kemerovo Region, the Republic of Khakassia, the Krasnoyarsk Territory and the Novosibirsk Region. Enterprises carry out production in both open and closed ways, but they all ship their products only by rail for export in the western or eastern direction.

The volume of coal production in the Republic of Yakutia is currently 20 million tons. By 2024, the coal miners of the republic plan to reach volumes of 80 million tons per year, which is already comparable to the volumes of production in Kuzbass. The growth in production volumes will be constrained precisely by the transport accessibility of deposits [5], which are $3000 \mathrm{~km}$ closer to Kuzbass by sea, which makes Yakut coals more competitive and less demanding for the development of the Eastern road of Russian Railways. The main contribution to coal mining is formed by two clusters. The first cluster is the newest - Elginsky, focused on the export of products via a private railway line from Elga to Verkhnezeysk, located on the BAM.The production volume of over 15 million tons for 2021 was recorded and the prospect of the increase in shipments up to 45 million tons was outlined. The second largest cluster of Yakutia is the Neryungrinsky (export by the AmurYakutsk railway from the Ignalinsky and Neryungrinsky deposits), consisting of 3 large coal mining enterprises with total plans to increase production to 20.5 million tons in the coming years. 
Buryatia deserves attention among other regions of coal production (Figure 2) that export coal. Mass shipment of coal takes place from the only large Tunguiskiy open-pit mine in the amount of about 8 million tons.

The production of coal of various grades by national producers has recently become a driver of growth in freight rail transportation by rail. Coal transportation is primary Russian Railways and key players in the rail transportation market due to the large and stable traffic volumes. Coal transport affects all the aspects of rail transport, including infrastructure maintenance and passenger train traffic.

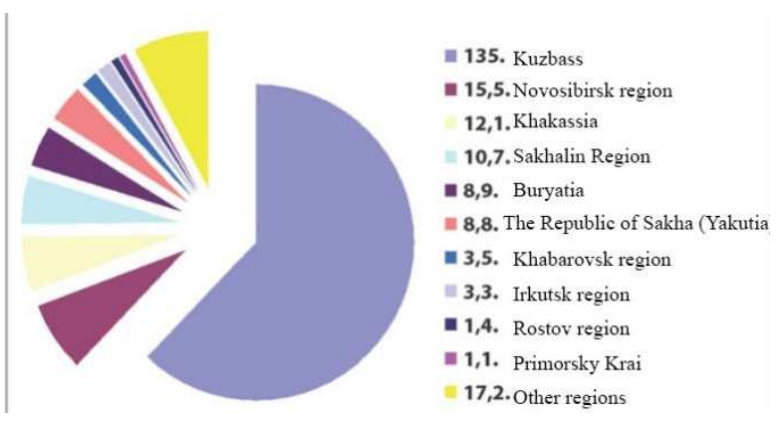

Figure 2. Export structure from coal mining regions in 2019, million tons (source - Kuzbass Business Portal)

Moreover it is necessary to note that the specificity of the Russian railway network, which consists in the ramified structure of the western part and the linearity of the eastern part of the railway. The western part of the Russian Railways network is an extensive network of railway lines, a number of which run parallel routes, which allows redirecting train traffic between them. The railway network in this part of Russia continues to be closely integrated with the railway systems of the CIS and Baltic countries, which also increases the flexibility and stability of the system.

Customers have the opportunity to direct export cargo flows to different ports and to different land border points. This specificity significantly reduces the severity of the problem of lack of carrying capacity in key areas, since the network has flexibility and maneuverability.

As it is known the eastern part of the Russian railway system has a linear structure, represented by two major highways running in the West-East direction: the Trans-Siberian Railway and the BaikalAmur Railway. These two highways are complemented by a number of auxiliary lines adjacent to them and connecting them to each other.It is the absence of an extensive network of railways in the eastern part of Russia that reduces the maneuverability of the network, lowers the reliability of transportation, worsens the problem of lack of carrying capacity and focuses the attention of the transport complex on the development of exactly two existing highways.

\section{Research of the limitations and prospects of railways}

Today Russian Railways is implementing a largescale investment project for the development of the carrying capacity of both railways in order to increase the traffic of goods to 180 million tons per year by 2024 in the direction of the ports of the Far East and land border crossings with China [6, 7, 8].The main purpose is to increase the transportation of coal and cargo in containers. For these purposes, it is planned to spend a total of more than 600 billion rubles. It will be spent on the development of both highways during the entire period of the project. However, the increase in the carrying capacity of railways on such a large training ground is going on with great difficulties and can not continue indefinitely. This process is taking place in steps. Moreover, the feasibility of financing further plans to develop the carrying capacity of up to 200 million tons or more for the future until 2030 and beyond is being discussed.

The actual limit of the technical capabilities of the mixed-traffic railway line is the equipment, which includes two main tracks, electrification with alternating current and the organization of heavy traffic of full-set trains of standardized length with 71 conventional wagons (1050 meters). Depending on local conditions, this allows transporting about 90 million tons of cargo per year on such a line in conditions of mixed traffic of heavy freight, passenger, suburban and express container trains. A further increase in the carrying capacity of the railway line, for example, through the construction of the third and fourth main tracks in real conditions is meaningless due to the multiple complications of such projects.If a further increase in freight traffic is required, priority should be given to the construction of new trunk lines due the improvement in the geography of transportation.

The volume of expensive investment measures, being implemented today and combined into two investment projects "Development of the Eastern Range" and "Transsib in 7 days" (acceleration of container transportation) actually boils down to the following:

- The intensification (renewal) of the locomotive fleet and power facilities of Russian Railways; 
- The development of technical stations, including sorting stations (technical re-equipment, lengthening of tracks, construction of new track parks), ensuring the train traffic passing;

- The extension of receiving and departure tracks up to a standard length of $1050 \mathrm{~m}$ at freight and intermediate stations;

- The construction of sidings on single-track sections and construction of continuous double-track sections on BAM and lateral lines between BAM and Trans-Siberian railway;

- The construction of the second lines of bridges and tunnels on the BAM.

These measures will make it possible to adjust the carrying capacity of two highways along their entire length and eliminate the so-called bottlenecks - local problem areas that hinder transportation. The geography of the location of these sections, according to various estimates, covers an extensive landfill with a length of 8 thousand $\mathrm{km}$ from the Kemerovo Region (West Siberian Railway - a branch of Russian Railways) to the ports of Primorye (Far Eastern Railway).

The important problem of transportation on the Eastern line is that the carrying capacity in the summer period is limited by the need to perform regular track works that require closure of traffic. The research and production unit of Russian Railways is making great efforts to optimize the infrastructure repair process [9-12], but still a big problem for both BAM and Trans-Siberian Railway is the presence of sections with overdue repair periods, that is, operated beyond the permissible duration. In summer months, there are situations when restrictions are imposed on the loading of goods to ports due to the congestion of trains on the Eastern range. This indicates that the release of railway capacity in summer is extremely acute.

In the logistics chain of the transportation of goods in export-import communications through the ports of the Far East, two transport hubs that have no alternative remain: Vladivostok-Nakhodkinsky and Vanino-Sovgavansky.The export shipment, including coal, is possible only through these large port regions that combine the railway and port facilities.Directly terminal (including berthing one) facilities and railways are currently being actively developed by the efforts of investors and the railway approaches are being reconstructed by the efforts of Russian Railways. In addition to the reconstruction and development of the existing terminals, such highperformance transshipment complexes as Vostochny Port, VaninoTransUgol and Vera were built.New terminals are being built in the bays of Muchka, Wrangel, Telyakovsky and Troitsa. However, currently unsolved and intractable task in the foreseeable future is the work of port transport hubs as a whole. The railway infrastructure of these port regions has a tree-like topology, which reduces the reliability of transport hubs. The decommissioning of any element (station, turnout, haul or, for example, a bridge) can lead to theoperation stop of a large number of enterprises. There is no possibility to redirect train flows in alternative routes both in the port regions themselves and in the approaches to them. The violation of the regularity of railway or sea transportation leads to the congestion of transport on the adjacent side, as a result of which there is an overflow of railway junctions, filling of port warehouses and disruptions in transportation [13, 14]. The objective necessity is the development of an alternative, third transportation channel for export cargo flows.

\section{Overview of the characteristics of waterways for coal transportation}

Amur is one of the largest rivers in the world. Reaching 2824 kilometers in length, this river is completely navigable. The source of the river is located at an altitude of 304 meters above sea level and is formed by the confluence of the Shilka and Argun rivers on the border of Russia and China.The river flows through the territory of the Khabarovsk Region, the Jewish Autonomous Region, the Amur Region and the Trans-Baikal Territory. The large tributaries of the Amur are the Shilka and Zeya rivers flow through the same regions. These rivers are considered below in this paper.

The sections of the inland waterways of the Amur River, suitable for navigation, from the mouth of Nikolaevsk-on-Amur to the villageJalindaare kept according to the $1^{\text {st }}$ category by the order of Federal Agency for Maritime and River Transport of Russia. That is, they guarantee the dimensions of the ship's passages and the illuminated navigation route. From the village of Jalinda to the confluence of the Argun and Shilka rivers, the inland water-ways of Amur River are kept according to the $2^{\text {nd }}$ category (the dimensions of the navigational passages and the reflective navigation situation are guaranteed). In the lower reaches, the guaranteed depths range from 1.9 to 4 meters and in the upper reaches to the source of the Amur, the guaranteed depths decrease to 1.0 m. The economic use of the Amur River can be characterized as moderate and the intensity of navigation, taking into account the size of the river, can be characterized as insignificant.

The Shilka River with a length of $559 \mathrm{~km}$ flows mainly through the territory of the Trans-Baikal Territory. It belongs to the 7 th category of waterways 
(inland waterways without guaranteed dimensions of ship passages and without navigational conditions). The duration of navigation on the Shilka averages 130-140 days and directly depends on the water levels. There is no centralized freight traffic on the Shilka, as there are no river transport enterprises that have a transport cargo fleet and a developed infrastructure for carrying out freight traffic in this region. The economic use of the Shilka River in general can be characterized as weak, although historically this waterway was of great importance in the development of the eastern borders of the Russian Empire. The intensity of navigation on Shilka can be characterized as extremely low.

The navigation along the Zeya River from its mouth in Blagoveshchensk to the Zeya hydro-electric power station is currently poorly developed and depends on the regimes of water discharge at hydroelectric power station. The entire lower river course up to the city of Zeya (Zeya hydroelectric power station) belongs to 1-2 categories of inland waterways, which creates favorable conditions for navigation. The Zeya reservoir also belongs to inland waterways and belongs to the $7^{\text {th }}$ category (which does not provide guaranteed depths) because of the lack of demand for active navigation due to the absence of large-scale industries on the banks of the reservoir. The Zeya hydro-electric power station, built in 1975, is not equipped with navigational devices and is an obstacle to through navigation on the Zeya River.The concrete dam with a height of 115 meters in terms of its dimensions is equivalent to the Krasnoyarsk hydroelectric power station, where the only ship lift in Russia was built, which indicates the technical feasibility of the construction of expensive ship pass structures. In the current conditions, shipping along the Zeya River can be described as low-intensive, represented by one-time deliveries of project cargo for gas chemical plants under construction in Svobodny.

In the transport strategy up to 2030 [15], the development of transportation in the Amur basin is mentioned without specific plans for attracting freight flows by the phrase "comprehensive reconstruction of inland waterways and hydraulic structures of the Ob-Irtysh, Yenisei, Lensky and Amur basins". This allows concluding that there are no comprehensive plans for the development of shipping along the Amur in the transport industry, even despite the lack of carrying capacity of the railways.

Historical aspect.As it is mentioned above, the Amur waterway had a great influence on the development of the Russian Far East in the period from the $17^{\text {th }}$ to the $20^{\text {th }}$ centuries. It was on the shores of the Shilka, Argun and Amur Rivers where the borders of Russia were born, the location of which was the subject of the first treaties with imperial China. The passage of the state border along the Amur has not changed for over 300 years.

During the active construction of the TransSiberian railway at the turn of the XIX-XX centuries there were several important stages when the advantages of the geographical location of the Amur Basin were used:

- the extension of the Trans-Baikal railway track from the shores of Lake Baikal to the Shilka River and the organization of mixed traffic in 19011903 period;

- the construction of a through railway track to the Pacific Ocean through Manchuria, the operation of the Chinese Eastern Railway (CER) in 1903-1916;

- the construction of the Trans-Siberian railway along the current route through Trans-Baikal, the Amur Region and the Khabarovsk Territory in 1906-1916 and the subsequent opening in 1916 of railway traffic from St. Petersburg to the Pacific Ocean entirely across the territory of Russia.

The city of Sretensk, founded on the banks of the Shilka River, managed to be the final point of the Siberian Railway in the period from 1901 to 1903, from the moment the construction of the TransBaikal section of the main line was completed until the opening of the Chinese Eastern Railway (CER). However, even with the opening of the CER, Sretensk remained an important transport hub, ensuring the transshipment of goods from the railway to river transport. The favorable geographical position made the city located on the Shilka River an important point on the map of the Russian Empire, the degree of importance of which began to decline only with the opening of a through railway communication along the Trans-Siberian Railway in 1916. In the same period, Blagoveshchensk was also provided with a railway connection and the city of Khabarovsk began to form.

During the revolution and the subsequent civil war, shipping in the Amur Basin played the important role in dramatic events. In the subsequent years of the formation of Soviet power and the development of the economy of the Far East, shipping on the Amur provided transportation of goods for the needs of the region [16].Transport and industrial construction projects, starting with the construction of the Trans-Siberian Railway included the delivery of goods in river traffic. The maximum volume of river traffic in the Amur basin was reached at the end of the $80 \mathrm{~s}$ of the $20^{\text {th }}$ century and amounted to more than 32 million tons. During the traffic crisis between 1990 and 2016, volumes fell by more than 
$90 \%$ to 3.1 million tons. At present, the structure of traffic volumes is such that construction cargo makes up $85 \%$ of the volume, liquid cargo $3.5 \%$, timber $3.5 \%$ and coal only $0.28 \%$. The remaining share of less than $8 \%$ comprises other cargo.

During the second half of the $20^{\text {th }}$ century, the importance of the Amur in the transport system of the Far East was constantly changing with the construction of railways, highways and the development of new territories. However the history of Russiaon the banks of this river showed that shipping along the Amur provided a solution to a number of transports, social and political problems. Taking into account the increasing demand for the transportation of bulk cargo, it is worth referring to the previously existing logistic schemes.

Border status. The Amur River along its length from the source to the city of Khabarovsk passes along the state border of Russia and China. The modern joint Russian-Chinese use of border rivers, including the Amur, was established by the SovietChinese agreement of 1951, which was extended by the agreement of 1994 [17] and exists today [17]. The provisions of this agreement establish parity conditions for navigation and maintenance of waterways. For this purpose, there is a joint international commission that implements the provisions of the Agreement. On the Russian side, the representatives of the Amur Waterway Administration (Administration of the Amur Basin of Inland Waterways in Khabarovsk) participate in the commission. The navigation in the Amur River basin is carried out according to the standard rules adopted for inland waterways in the Russian Federation [19, 20]. The maintenance of the waterways of the border sections of the Amur water basin is carried out jointly by the Russian and Chinese parties.

Special requirements for navigation in border areas are imposed only in terms of mooring and carrying out cargo operations. In the absence of force majeure circumstances, berthing of vessels for any purpose is allowed only at designated places and only on the coast of the vessel's home country.Moreover, Russian ships and their crews are prohibited from interacting with the crews of ships of Chinese jurisdiction that have not passed customs and border control in Russia.

The stay of ships in the border areas of the Amur basin in the dark is allowed according to the order [21] only if they have means of control, in agreement with the border authorities. The power cut of these means is not allowed.

According to the analysis of the current rules of navigation and the current regime of the state border on the border sections of the Amur River, it can be concluded that there are no objective difficulties and obstacles for intensive navigation caused by the special legal status of the river as a state border. The current legal conditions are favorable.

\section{Perspective logistic scheme}

The analysis of the current state of transportation of bulk cargo for export in the eastern part of Russia showed the demand for the use of river transport in the form of the Amur River basin. At the moment, the advantages of river transport are becoming more and more popular, such as low cost of transportation, the ability to transport large consignments of goods, ease of transshipment to sea transport, relatively high reliability and environmental friendliness. The start of the third channel for the supply of coal along the Amur, in addition to two existing port regions, will diversify supplies, reduce the load on key links of the transport system and free up the throughput capacity of the Eastern range of Russian Railways in the summer months for track work.The Amur Waterway will allow realizing the advantages of synchromodal transportations [22-24], achieved due to the availability of prompt redirection of traffic flows between main transport modes. Some of these principles are currently already being applied during the redirection of goods of various owners between ports. Cross-servicing of ships and trains by competing owners on each other's infrastructure is being practiced. With the start of a river supply channel, such logistic approaches can have an even greater positive effect.For example, in the case of supply disruptions at the Nakhodka transport hub, a part of the cargo can be additionally switched from the railway in Khabarovsk or Blagoveshchensk to river transport and vice versa - in case of unfavorable weather conditions on the Amur or Shilka Rivers, a part of the freight traffic will be switched back to the railway for delivery through Vanino or Nakhodka. Figure 3 shows the proposed logistic scheme for the delivery of coal for export in the Far Eastern region and the possible volumes of switching export coal transportation for three most suitable jets of cargo flows:

1. The freight traffic of Kuzbass presented by the ports in the volume of 80 million tons, currently being routed along BAM and Trans-Siberian Railway, is proposed to be divided into a completely railroad leg (especially in winter months) and a rail-water leg. Reloading onto river transport will be required in the vicinity of Sretensk from the inactive Kuenga-Sretensk railway line to shallow-draft trains for transportation along the Shilka and Amur rivers to the very mouth of the Amur.The transshipment from river vessels to sea bulk 
carriers can be organized both in the port of Nikolaevsk-on-Amur and in any of the coastal ports:Sovetskaya Gavan/Vanino, Nevelsk/Shakhtersk (Sakhalin Island) or Nakhodka/Vladivostok. The advantage of coastal ports is a well-developed port a) Logistic scheme of Kuzbass-export transportation infrastructure for handling coal cargo flows. A preliminary assessment shows that it is promising to switch to river transport up to 15 mln tons of cargo per year, which with 140 days of navigation is equivalent to unloading about 17 heavy trains per day. Trans-Siberian Railway

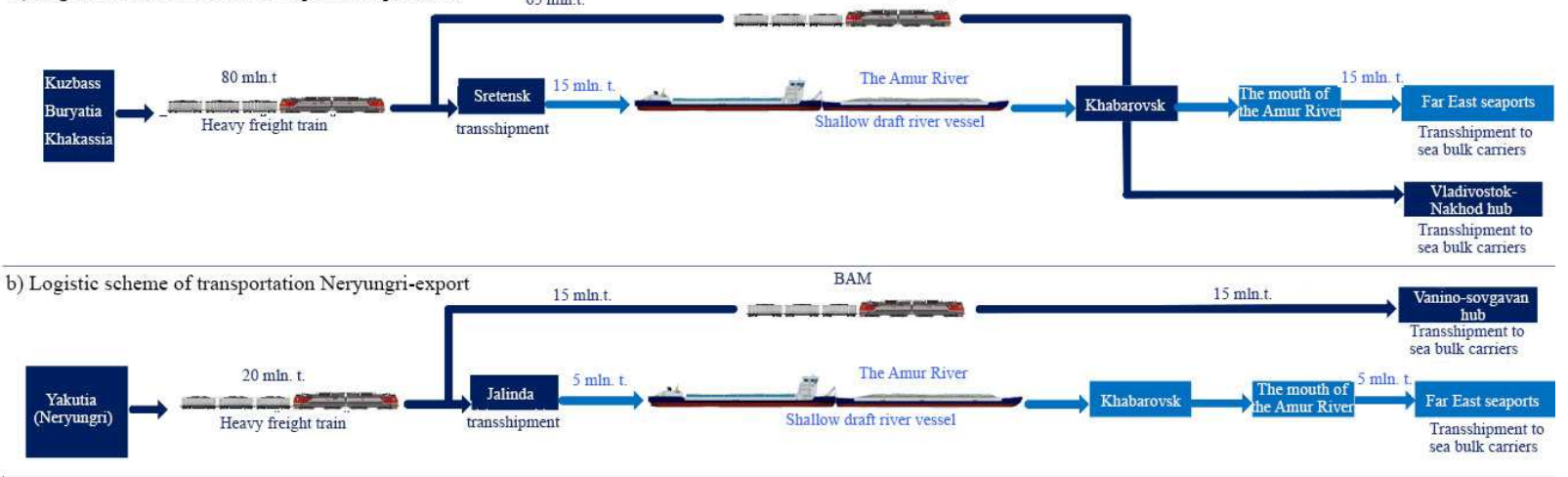

c) Logistic scheme of Elga-export transportation

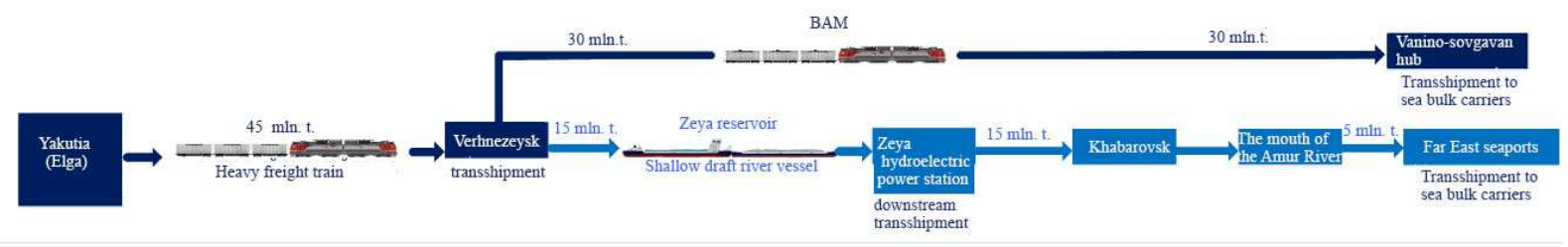

Figure3. Proposed logistics schemes for the delivery of coal for export

1. Freight traffic of Neryungri (Yakutia) (ports in the volume of 20 million tons, currently being routed through the BAM and Trans-Siberian railway) is also proposed to be divided into two legs. The first assumes the transportation of 15 million tons by the existing railway route and the second in the volume of about 5 million tons in railway and river communication through the stations of Tynda and Skovorodino to the transshipment station in the village Jalinda on the Amur River. From the village Jalinda the transportation by river vessels along a similar route to seaports will be needed.

2. Freight traffic of Elga (Yakutia) (ports in the volume of 45 million tons, currently directed exclusively through the BAM to the port of Vanino) is proposed to be divided in the ratio of 30 million tons for the railroad leg and up to 15 million tons for the rail-water leg with delivery along the Zeya and Amur Rivers through Blagoveshchensk. The implementation of this logistic scheme is associated with additional difficulties, the main of which is the need for cargo ships to overcome the Zeya HPS. This can be realized either in the form of additional transshipment of cargo, or in the form of construction of a ship elevator similar to the ship elevator of the Krasnoyarsk HPS. Theoretically a similar logistic scheme can be considered for the large Urgal coal cluster, located on the banks of the Bureya River, which also flows into the Amur River. However, there are already two hydroelectric power plants on the Bureya, which are also impossible to cross by river vessels at the moment. 


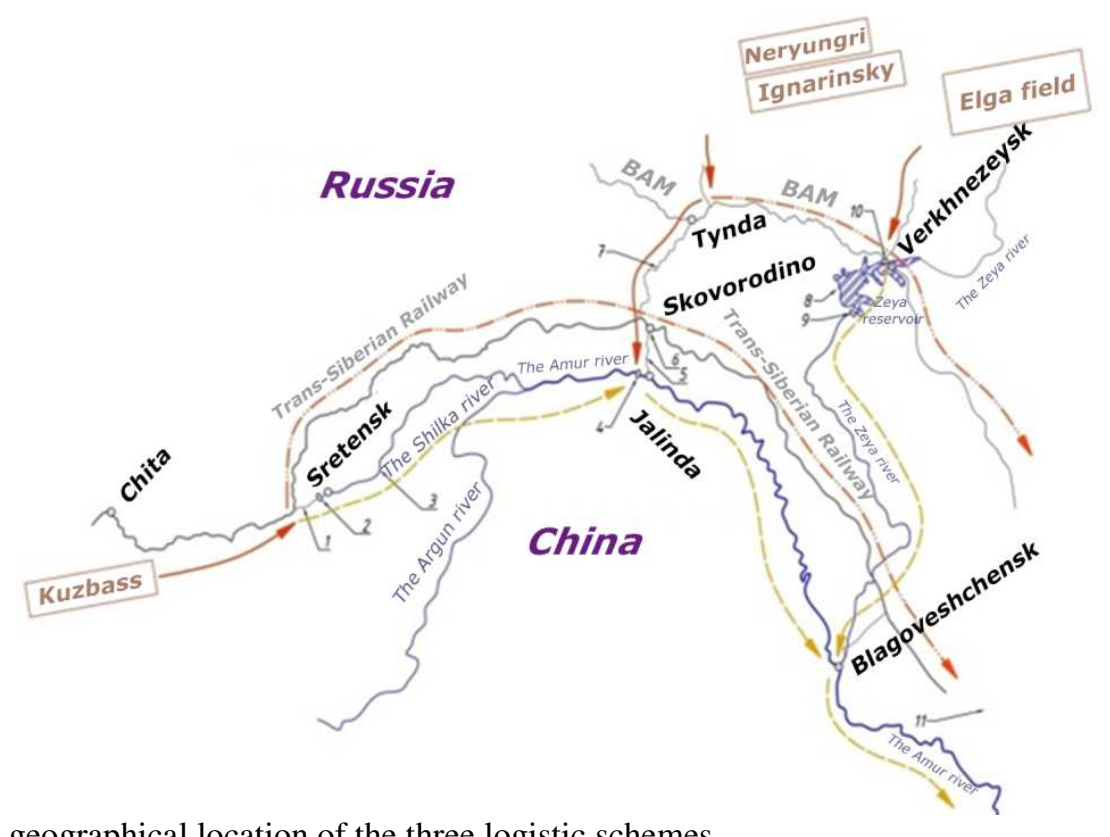

Figure 4. Mutual geographical location of the three logistic schemes

In order to switch the listed cargo flows of 35 million tons per year of coal to the Amur River basin and to unload the most congested sections of the Eastern landfill of Russian Railways, a complex of capital-intensive investment measures is required, the location of which is shown in Figure 4:

1. The development of two low-performing railway lines that are currently unprofitable for Russian Railways: the Skovorodino - Reinovo (Jalinda) line and the Kuenga - Sretensk line (1 and 5 on the map). The improvement of the roadbed, construction of overpasses with the Trans-Siberian Railway and renovation of artificial structures will be required.

2. The Skovorodino - Reinovo line for the organization of heavy traffic on it will require major repairs and rehabilitation of the roadbed. As it is known, in order to improve the financial result for the operation of such lines, either cost sequestration or the development of freight or passenger traffic is required [25]. The appearance of such large cargo flows on these lines will transfer them to the status of cargo-intensive. The volume of investments by Russian Railways in the overhaul of these lines can be estimated at 2-3 billion rubles.

3. The construction of transshipment stations with port facilities (berths, dredging, storage tanks) in the vicinity of Sretensk and the settlements of Jalinda and Verkhnezeysk, as well as the measures to lengthen the receiving-departure tracks of other separate points up to $1050 \mathrm{~m}$, equipping stations with signaling systems (activities 2, 4 and 10 on the map).

4. The reconstruction of the Skorovodino railway hub (6 on the map) and development of the
Skovorodino - Tynda railway section (7) to improve the conditions for passing train traffic towards Reinovo station (Jalinda). With the increase in the size of train traffic on the BAM - Skovorodino section to Reinovo, it may be necessary to build a third main track.

5. The improvement of navigation conditions on the Shilka, Zeya and Amur Rivers (3 and 8 on the map). For the development of mass transportation of goods, it is necessary to improve the navigation conditions and raise the inland water-ways class along the Shilka River to 1-3 classes and ensure the conditions for navigation along the Amur [26]. The development of transportation along the Zeya reservoir, with appropriate justification, will also require the equipment of waterways for round-theclock navigation the Zeya HPP is designated as a separate event under number 9. For the development of navigation conditions by Amur Waterway and increasing the content category of the inland waterways of the Shilka and Zeya Rivers, Federal Agency for Maritime and River Transport of Russia must receive the volume of cargo confirmed for transportation, the range of cargo, the composition and number of the fleet, the name and readiness of the loading / unloading points, the expected period of transportation in accordance with the established procedures from the Government of the Trans-Baikal Territory and the Amur Region in the section from Verkhnezeisk to the hydroelectric power station. The provision of transportation by water transport through. 


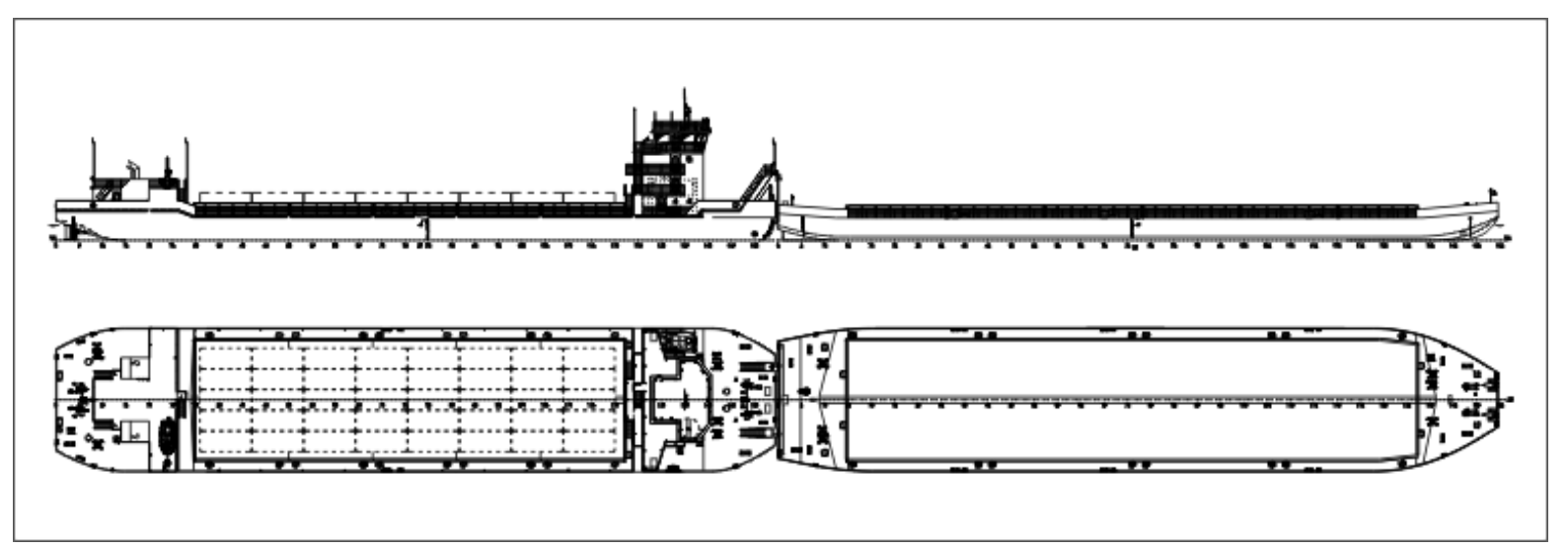

a

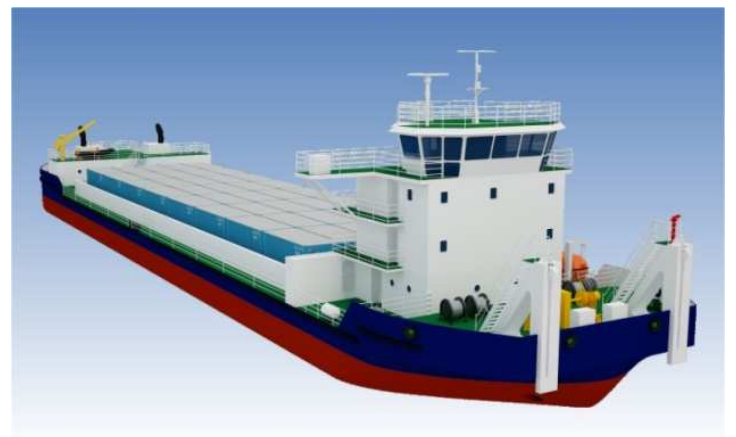

b

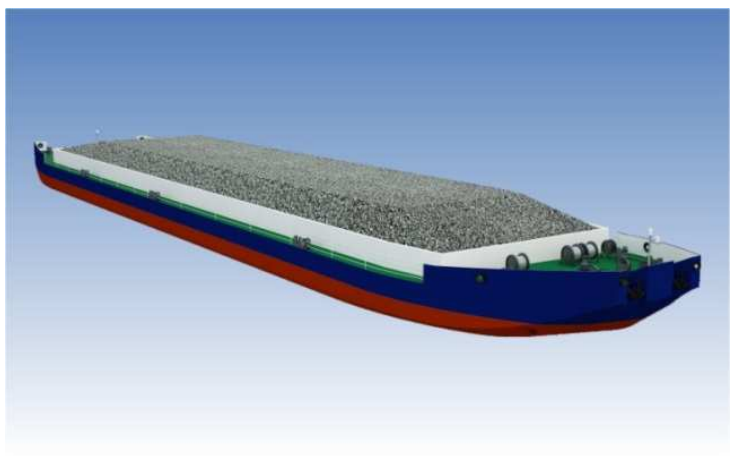

c

Figure 5. Shallow draft dry-cargo train for the eastern basins with a total deadweight of 4788 tons: a) tug-barge train (TBT) from vessels of projects RD63 and RDB21); b - shallow-draft self-propelled dry-cargo vessel- pusher platform; c - shallowdraft non-self-propelled multipurpose river deck dry-cargo vessel of RDB21 project

6. As a separate event (11 on the map), it is necessary to note the provision of economically and environmentally optimal transshipment of coal from river vessels to sea vessels in one of the Far Eastern ports listed above. Apart from the measures for the development of infrastructure, there is a set of measures for the purchase of a cargo fleet specialized for transportation along rivers with shallow depths. For these purposes, for example, the vessels of projects RD63 and RDB21 (Figure 5), developed by the Marine Engineering Bureau, are preferable.

7. At the stage of a more detailed technical and economic assessment, the size of the required fleet will be determined, the size of which should be several hundred vessels. Far Eastern shipyards have not built such volumes of river vessels [27] and it will be necessary to deploy production at all shipbuilding facilities of the Amur Basin (Sretensk, Blagoveshchensk, Khabarovsk, Komsomolsk-onAmur and Vladivostok). In addition, it will be necessary to intensify the fleet in order to provide track operations on the considered rivers.

\section{Conclusion}

The authors of this paper call transport workers and representatives of the coal mining industry to more careful consideration of the possibility to organize the transportation of export cargo flows of coal along the rivers of the Amur River basin.This research requires a deeper study of all links of the proposed logistics chain. The estimates of the prospects for the extraction and subsequent transportation of coal, presented in the article, show a great demand for the emergence of a new channel for the supply of coal for export through the Far Eastern ports. The most optimal is the development of river supplies according to the presented logistic schemes in the railway-water communication. The release of the Trans-Siberian and Baikal-Amur railways in the summer months (navigation period on the Amur) from 35 million tons of coal will improve the conditions for track work on the railway, attract highly profitable cargo to rail transport and make the transport system more balanced. 


\section{References}

[1] Business portal of KuzbassRetrieved from: https: //www.avant-partner.ru/style/8188.html

[2] Ya. Ya.Eglit, K. Ya. Eglite, V. P. Pyankova, D. A.Glushko,Jekspluatacija morskogo transporta3 (96), 55-58 (2020).

[3] Y. Y.Eglit, A. A. Kovtun, K. V. Tishina, A. A.Dmitriev, Jekspluatacija morskogo transporta2 (91)9-12 (2019)

[4] Order of the Government of the Russian Federation No. 1582-r."Program for the development of the coal industry in Russia for the period up to 2035"(13.06.2020)

[5] The rate of export of coal from Kuzbass for export in 2021 is about 53 million tons: a victory or a draw?Retrieved from:https://www.rzd-partner.ru/zhdtransport/comments/norma-vyvoza-uglya-izkuzbassa-na-eksport-v-2021-godu-v-obeme53-mln-tonn-pobeda-ili-nichya/.

[6] A. F.Borodin,Railway transport,8,34-42, (2017)

[7] F.S.Pekhterev,Economy of railways, 2, 60-65, (2015)

[8] Yu. N.Fedorov, Railway transport, 7,510,(2019)

[9] Yu. M.Krakovskii,V. A. Nachigin, Modern technologies. System analysis. Modeling,2, (66),109-115, (2020) DOI: 10.26731/18139108.2020.2(66).109-115

[10] M. I.Mekhedov,Actual problems of the development of railway transport 17-25 (2019)(Moscow: RAS)

[11] V. A.Nachigin,S E Stepanets,Transport of the Asia-Pacific region, 1(10), 6-8, (2017)

[12] M. I.Mekhedov,E. A. Sotnikov,P. S. Kholodnyak, D. A. Kursin,N. B. Kornienko,VNIIZHT Scientific Journal,80(1), 4-12, (2021)

[13] L. A.Muginshtein,M. I.Mekhedov, Vniizht Bulletin (Railway Research Institute Bulletin), 2, 6-13,(2014)

[14] A. T.Osminin,M. I. Mekhedov, D. V. Mednikov,Railway transport, 7, 11-17, (2019)

[15] Order of the Government of the Russian Federation No. 1734-r. "on the approval of the Transport strategy of the Russian Federation for the period up to 2030" (22.11.2008)

[16] L Y Kremko,The main trends in the development of legal science. (Khabarovsk: Pacific State University, 2020)

[17] Agreement on the procedure for navigation along the border rivers Amur, Ussuri, Argun, Sungach and Lake Khanka No. 1826$876 s(30.05 .1951)$
[18] Agreement between the Government of the Russian Federation and the Government of the People's Republic of China on the regime of the Russian-Chinese state border (27.05.1994)

[19] Order No. 32 "On the introduction of" Regulations on the provision of information to shipowners and navigators on the navigation conditions on the inland waterways of the Russian Federation "'"(30.05.1995)

[20] GOST-26775-97 "Interstate standard Dimensions of bridge spans of bridges on inland waterways" (01.01.1998).

[21] Order of the FSB of Russia No. 454 "On approval of the rules of the border regime"(7.08.2017)

[22] P. V.Kurenkov,D. A. Preobrazhensky,A. V. Astafiev,A. A. Safronova,D. G. Kakhrimanova,Railway transport,3, 30-35, (2019).

[23] A. V.Astafiev,D. G. Kakhrimanova,M. V. Kizimirov, D. A. Preobrazhensky,L. K. Egerman,Transport Bulletin,8, 12-15, (2018)

[24] D. A.Preobrazhensky,F. K. Mukhamadshoev, A. A. Kosyreva, E. V. Moiseenko, L. V.Chaikina,Transport Bulletin, 2, 1931,(2020)

[25] S. P.Vakulenko,A. V. Kolin,N. Yu. Evreenova, D. Yu.Romensky,K. V. Golikov Efficiency of operation and maintenance of low-intensity railway lines(Moscow: VINITI RAN, 2018)

[26] T. N.Mikhailova, T. V. Pilipenko, Amur River transport (XXI century), 1 (93), 52-53, (2020)

[27] I. V.Kamenskikh,O. A. Nezhinskaya, Production technologies of the future: from creation to implementation. - Komsomolsk-onAmur: Komsomolsk-on-Amur State University, pp. 136-139,(2019) 